\title{
Comparison of ondansetron and low dose Ketamine as agents for prevention of intraoperative nausea and vomiting during caesarean section under spinal anaesthesia
}

\author{
Ovais Nazir $^{1 *}$, Asif Hussain Bhat ${ }^{2}$, Hamid Yatoo ${ }^{3}$, Amit Khatuja ${ }^{4}$, Rajesh Misra ${ }^{5}$ \\ ${ }^{1-3}$ Senior Resident, ${ }^{4}$ Senior Consultant, ${ }^{5}$ Chairperson and Head, Dept. of Anesthesiology, ${ }^{1-3}$ Aruna Asif Ali Government Hospital, New \\ Delhi, ${ }^{4,5}$ Artemis Health Institute, Gurugram, India
}

*Corresponding Author: Ovais Nazir

Email: ovais.khan83@gmail.com

Received: $23^{\text {rd }}$ November, 2018

Accepted: $6^{\text {th }}$ December, 2018

\begin{abstract}
Introduction: Spinal anaesthesia is considered as gold standard for caesarean section due to its advantages of rapid and predictable onset, no airway handling, safe to mother and minimal drug exposure to fetus. But spinal anaesthesia caesarean section is associated with high incidence of IONV. Role of ondansetrone as antiemetic is well established. Not many studies are there for low dose ketamine in prevention of IONV.

Materials and Methods: A total of 225 pregnant patients scheduled for CS under spinal anaesthesia were included and divided into three groups Group I - Patients who received low dose ketamine, group II- Patients who received ondansetron, group III- Patients who received normal saline. The patients were compared for intraoperative hemodynamic parameters, IONV, side effects like sedation and shivering.

Results: The results of this study showed low dose ketamine group (group I) $26.6 \%$ and ondansetron (group II) $32 \%$ had lower incidence of IONV in comparison to control group $49.3 \%$.

Conclusion: Low dose ketamine and ondansetron are both good agents for reduction of IONV during CS in pregnant patients under spinal anaesthesia without significant adverse effects.
\end{abstract}

Keywords: Ondansetron, Ketamine, (IONV) Intraoperative nausea vomiting, (CS) Caesarean section, (NMDA) N- methyl D-aspartate, (ASA) American society of Anaesthesiology.

\section{Introduction}

Spinal anaesthesia is the most commonly used anaesthesia for caesarean section with it being safely, quickly and easy to administer. ${ }^{1}$ Current literature indicates a high incidence of intraoperative nausea and vomiting during caesarean section under spinal anaesthesia for which many factors may contribute like hypotension, stimulation of pharyngeal reflex noticed in abdominal surgeries, physical rupture and manipulation of abdominal viscera, due to the release of humoral 5-HT substances, which trigger the $5-\mathrm{HT}_{3}$ receptors on vagal afferent neurons., ${ }^{2,3}$ During abdominal surgery under regional anesthesia, nausea may happen due to several contributing factors such as sympathetic blocks followed by parasympathetic dominance with hypotension which is the most important cause of nausea after spinal anesthesia, decreased perfusion of central nervous system, anxiety, and sudden abdominal movements during surgery and prescription of drugs. ${ }^{4}$

Ondansetron is considered as an effective drug for prevention and treatment of nausea and vomiting that is well tolerated by the patients. ${ }^{3}$ It is used in surgeries which may be accompanied by nausea and vomiting without many severe adverse side effects. ${ }^{5}$ Ketamine is a NMDA receptor antagonist that has unique central sympathomimetic, vagolytic and analgesic properties. ${ }^{6,7}$ These properties of ketamine are assumed to reduce the incidence of spinal induced hypotension consequently nausea and vomiting.

The present study was undertaken to compare the anti emetic efficacy of low dose ketamine and ondensetron to decrease the incidence of IONV during CS under spinal anesthesia.

\section{Materials and Methods}

After approval by institutional ethical committee and obtaining a written informed consent from patients, this study was done in the time period from January 2016 to August 2017. We studied a total of 225 patients aged from 20 to 40 years who were scheduled to undergo caesarean section under spinal anaesthesia. Exclusion criteria included history of motion sickness, post-operative nausea and vomiting, allergy to (bupivacaine, fentanyl, ondansetron or ketamine), ASA grade 3 or more, pregnancy induced hypertension, smoking, obese patients (body weight $>80$ $\mathrm{kg}$ ), epileptic patients, patients given antiemetics or corticosteroids within $24 \mathrm{~h}$ before CS, and patients having contraindications to spinal anaesthesia. Included patients were allocated randomly (using computer generated randomization table) into three equal groups: Group I- the ketamine group $(\mathrm{n}=75)$, group II-the ondansteron group $(n=75)$ and group III-the control group $(n=75)$. The drugs used were prepapred by a separate anaesthesiologist in a syringe diluted to total volume of $5 \mathrm{ml}$ syringe (In the ketamine group- Ketamine $0.25 \mathrm{mg} / \mathrm{kg}$ bodyweight diluted in $5 \mathrm{ml}$ saline, in the ondansetron group- Ondensetron $4 \mathrm{mg}$ in $5 \mathrm{ml}$ saline and In the control group $5 \mathrm{ml}$ normal saline) given after clamping of umbilical artery.

\section{Preanaesthetic Preparation}

All patients were hospitalized and kept fasting for at least 6 hours before surgery. A 18-G cannula was inserted and Ringer lactate infusion started 15 min before shifting the patient to the main operating theatre. In the operating room, patients were monitored with ECG, noninvasive arterial blood pressure and pulse oximetry. All patients were 
reminded to report any side effect or discomfort including nausea during surgery.

\section{Anaesthesia}

Anaesthesia was standardized, by giving spinal anaesthesia in the lateral position using a 25-Guage pencil point type spinal needle, 25 microgram fentanyl and 2.2 to $2.5 \mathrm{ml}$ (depending on height of patient) of hyperbaric bupivacaine $0.5 \%$, once free flow of clear CSF was obtained. All the patients were immediately returned to supine position after subarachnoid injection, table given 1520 degree left tilt and supplemented with oxygen 4 L min_1 via facemask. Sensory block was assessed by pinprick method and above T-6 dermatomal level was the acceptable level before surgical incision. Patients in whom the level of analgesia was insufficient were excluded from the study. Mean arterial blood pressure (MAP) was measured every $3 \mathrm{~min}$ for the first $10 \mathrm{~min}$ then every $5 \mathrm{~min}$ thereafter till end of surgery. Hypotension was treated with ephedrine $3 \mathrm{mg}$ and bradycardia was treated with atropine $0.6 \mathrm{mg}$. Oxytocin was given immediately after baby delivery and clamping of the umbilical cord starting by an IV bolus dose of ( 3 units) followed by infusion of 10 units in $500 \mathrm{ml}$ saline at rate $125 \mathrm{ml} / \mathrm{hr}$ or according to uterine contractility and as per the obstetrician opinion. The $5 \mathrm{ml}$ of the prepared drug was given just after clamping of umblical cord. Intraoperative nausea was recorded as follow (no nausea, nausea only, nausea and vomiting single episode, More than one episode of intraoperative nausea and vomitting). Nausea with retching or vomiting were managed by a rescue dose of $8 \mathrm{mg}$ dexamethasone, while nausea only was managed by assurance. Maternal side effects (such as desaturation, hallucinations, shivering) as well as fetal well-being (assessed with the Apgar scoring) were recorded. Maternal sedation was assessed by Ramsay Sedation Scale (RSS; 1 =anxious and agitated, $2=$ co-operative and tranquil, $3=$ drowsy but responsive to command, $4=$ asleep but responsive to glabellar tap, 5= asleep with a sluggish response to tactile stimulation, $6=$ asleep and no response).

The three groups were then compared with reference to patient's characteristics, intraoperative clinical data (intraoperative hemodynamics, intraoperative nausea and vomiting, sedation).

\section{Statistical Analysis \\ Sample Size and Sample Technique}

The response within each subject group was normally distributed with standard deviation 2 . We needed to study minimum 64 experimental subjects in each group to be able to reject the null hypothesis that the population means of the experimental groups are equal with probability (power) 0.8 . The Type I error probability associated with this test of this null hypothesis is 0.05 .

\section{Data Analysis}

Statistical analysis was performed by the SPSS program for Windows, version 17.0. Continuous variables were presented as mean $\pm \mathrm{SD}$, and categorical variables as absolute numbers and percentages. Data was checked for normality before statistical analysis using Shaipro Wilk test. Normally distributed continuous variables were compared using ANOVA. Student $t$-test was used to compare between three groups of normally distributed data categorical variables were analyzed using the chi-square test. For all statistical tests, a p-value less than 0.05 were taken to indicate a statistically significant difference.

\section{Results}

There were no significant differences between the groups in terms of baseline patient characteristics $(p>0.05)$ (Table 1)

Table 1: Demographic data and hemodynamic parameters as mean \pm SD

\begin{tabular}{|l|c|c|c|c|}
\hline \multirow{2}{*}{$\begin{array}{c}\text { Demographic data and baseline } \\
\text { preoperative parameters }\end{array}$} & $\begin{array}{c}\text { Group I } \\
\mathbf{n = 7 5}\end{array}$ & $\begin{array}{c}\text { Group II } \\
\mathbf{N = 7 5}\end{array}$ & $\begin{array}{c}\text { Group III } \\
\mathbf{N = 7 5}\end{array}$ & \multirow{2}{*}{$\boldsymbol{P}$ value } \\
\cline { 2 - 4 } & (Ketamine) & (Ondansetron) & (control) & \\
\hline Age $($ years $)$ & $27.6 \pm 2.5$ & $28.8 \pm 2.2$ & $26.9 \pm 2.8$ & 0.52 \\
\hline Weight $(\mathrm{kg})$ & $70.35 \pm 4.3$ & $69.5 \pm 4.2$ & $69.7 \pm 5.3$ & 0.54 \\
\hline $\mathrm{MAP}(\mathrm{mmHg})$ & $77.1 \pm 6.9$ & $79.04 \pm 7.8$ & $78.7 \pm 5.8$ & 0.73 \\
\hline HR/min & $78.5 \pm 4.2$ & $75.29 \pm 6.9$ & $79.6 \pm 4.4$ & 0.54 \\
\hline SBP=Systolic blood pressure, $\mathrm{DBP}=$ Diastolic blood pressure, HR=Heart rate, SD=Standard deviation \\
\hline
\end{tabular}

There were lower incidences of hypotension in ketamine group and MAP and HR was higher (statistically insignificant) in the Ketamine group as compared to ondansetron and control group. 


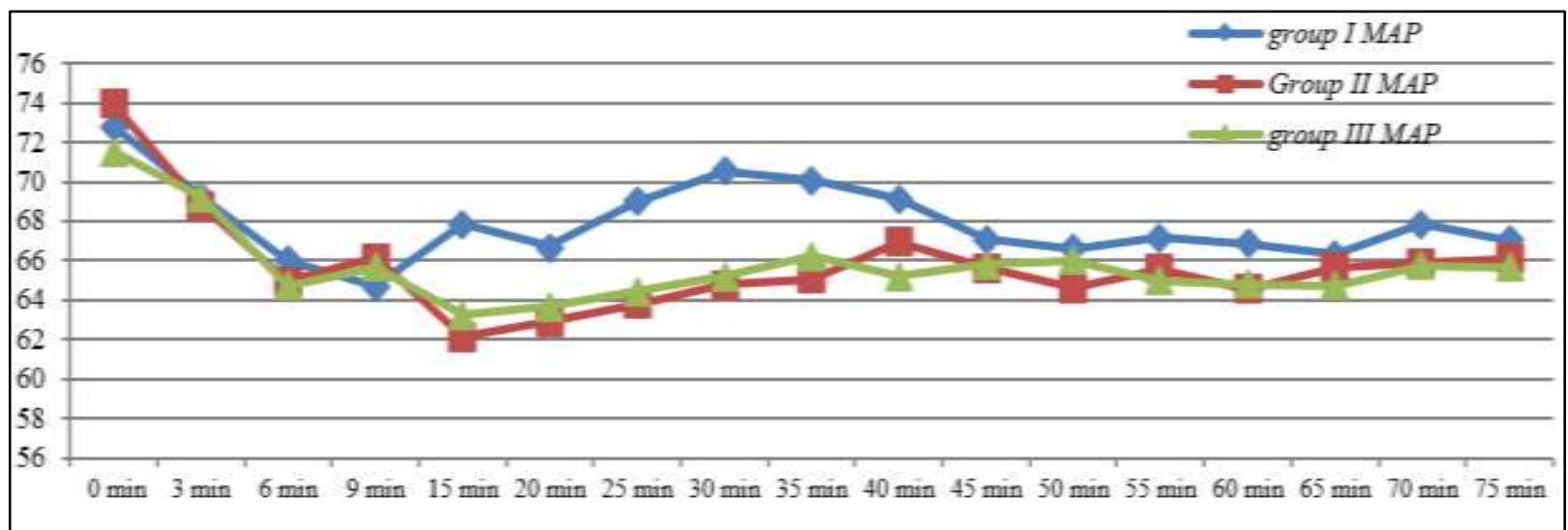

Fig. A: Mean arterial pressure variation (MAP)

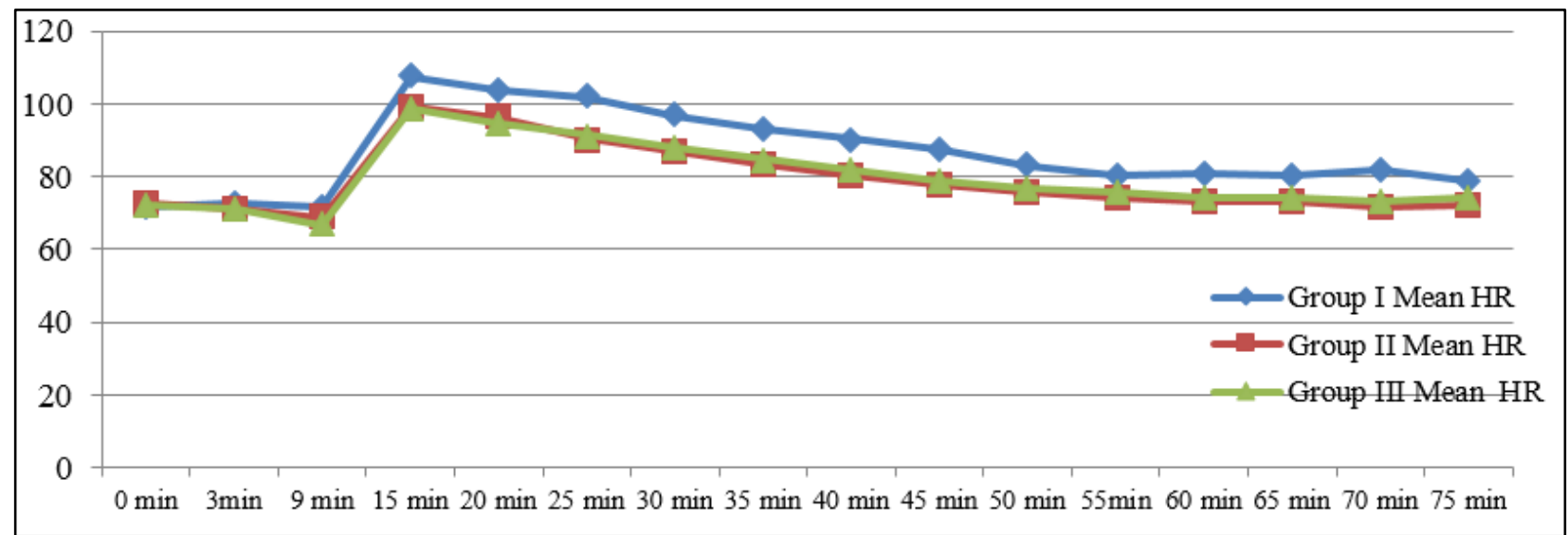

Fig. B: Mean heart rate variation (HR)

The incidence of intraoperative nausea in the ketamine group 26.6\% (20 out of 75) compared with Ondansetron $32 \%$ (24 out of 75) and control group 49.3\% (37 out of 75), which was statistically significant between group I and Group III, GroupII and Group III, and insignificant between Group I and Group II. Both vomiting episodes and number of patients who required rescue anti-emetics in the ketamine group and ondansetron group were less compared with control group.

Table 2: Nausea and vomiting episodes

\begin{tabular}{|l|c|c|c|c|c|c|}
\hline & $\begin{array}{c}\text { Group I } \\
\mathbf{N = 7 5}\end{array}$ & $\begin{array}{c}\text { Group II } \\
\text { N=75 }\end{array}$ & $\begin{array}{c}\text { Group III } \\
\text { N=75 }\end{array}$ & $\begin{array}{c}\text { P value } \\
\text { Group I } \\
\text { \& group } \\
\text { II }\end{array}$ & $\begin{array}{c}\text { P value } \\
\text { group I } \\
\text { \& III }\end{array}$ & $\begin{array}{c}\text { P value } \\
\text { Group II } \\
\text { \& III }\end{array}$ \\
\cline { 2 - 7 } & (Ketamine) & (Ondansetrone) & (control) & & & \\
\hline No nausea & 56 & 52 & 40 & 0.52 & $0.004^{*}$ & $0.003^{*}$ \\
\hline Nausea only & 9 & 11 & 18 & 0.54 & 0.06 & 0.24 \\
\hline Nausea and Vomitting 1 episode & 7 & 8 & 11 & 0.73 & 0.13 & 0.23 \\
\hline $\begin{array}{l}\text { Nausea and Vomitting more than 1 } \\
\text { episode }\end{array}$ & 3 & 4 & 6 & 0.66 & 0.24 & 0.27 \\
\hline Rescue antiemetic dexamethasone & 10 & 12 & 17 & 0.24 & 0.1 & 0.26 \\
\hline $\begin{array}{l}\text { Total Intraoperative nausea \& } \\
\text { vomitting }\end{array}$ & $20(26.6 \%)$ & $24(32 \%)$ & $37(49.3 \%)$ & 0.21 & $0.004^{*}$ & $0.029^{*}$ \\
\hline
\end{tabular}

Only 11 patients of Group I had Ramsay sedation score of 3 or more while in ondansetron and control group had postoperative RSS 2. 
Table 3

\begin{tabular}{|l|c|c|c|c|}
\hline & RSS & $\begin{array}{c}\text { Group I } \\
\mathbf{n = 7 5}\end{array}$ & $\begin{array}{c}\text { Group II } \\
\mathbf{N = 7 5}\end{array}$ & $\begin{array}{c}\text { Group III } \\
\mathbf{N = 7 5}\end{array}$ \\
\cline { 2 - 5 } & & (Ketamine) & (Ondansetron) & (control) \\
\hline Post op Sedation Score RSS & 1 & 0 & 0 & 0 \\
\cline { 2 - 5 } & 2 & 64 & 75 & 75 \\
\cline { 2 - 5 } & 3 & 10 & 0 & 0 \\
\cline { 2 - 5 } & 4 & 1 & 0 & 0 \\
\cline { 2 - 5 } & 5 & & & 9 \\
\hline Intraoperative shivering & & 4 & 7 & \\
\hline
\end{tabular}

\section{Discussion}

Spinal anaesthesia is considered as gold standard for caesarean section due to its advantages of rapid and predictable onset, no airway handling, maternal safety and minimal drug exposure to fetus. But spinal anaesthesia is associated with intraoperative hypotension, and IONV. IONV is an uncomfortable feeling for patients, causes surgical problems to obstetricians, and may increases the risk of visceral injury during surgery because of the involuntary uncontrolled abdominal movements. ${ }^{1,2}$

Nausea and vomiting during spinal anaesthesia has been associated with multiple factors like sympathetic blocks followed by parasympathetic dominance, hypotension which is the most important cause of nausea after spinal anesthesia, decreased perfusion of central nervous system, psychological changes (anxiety), and sudden abdominal movements during surgery and concomitant opioid administration. ${ }^{4,8,9}$ There are many drugs used for treatment of PONV in parturients undergoing CS under spinal anaesthesia like metoclopramide, domperidone, phenothiazines, butyrophenones, anticholinergics, antihistamines and ondansetron. ${ }^{10}$ These drugs have been used either alone or in combination and have proved effective for prevention of nausea and vomitting. Ondansetron is a selective antagonist of the 5hydroxytryptamine $\left(5-\mathrm{HT}_{3}\right)$ receptors and is a very effective agent in the prevention and treatment of nausea and vomiting. It is effective in the prevention and treatment of chemotherapy induced, ${ }^{11}$ intraoperative ${ }^{12}$ and postoperative nausea and vomiting. ${ }^{13,14}$ Hypotension is probably the most important cause of IONV that occurs during CS under spinal anesthesia. Hypotension can induce the emetic symptoms by leading to cerebral hypoperfusion. ${ }^{15}$ Prevention of hypotension is therefore important for the prevention of IONV. ${ }^{16} \mathrm{We}$ took the necessary measures like fluid administration at faster rate after making patient supine and using ephidrine to manage hypotension in all of our patients. We used ondansetron $4 \mathrm{mg}$ as at this dose it has been found to effective in the prevention of IONV during CS under spinal anaesthesia. ${ }^{17,18}$ Of the different agents used, droperidol $2.5 \mathrm{mg}$ and $5 \mathrm{mg}$ has been used in controlling nausea and vomiting in CS, ${ }^{19,20}$ dexamethasone $8 \mathrm{mg}$ and metachopromide $10 \mathrm{mg}$ also have been quiet effective in controlling nausea and vomiting during $\mathrm{CS}^{21,22}$ and have been compared for their effectiveness. ${ }^{23}$ Glycopyrrolate, due to its vagolytic effect was studied in prevention of intraoperative nausea and vomiting during CS and compared with ondansetron. It was seen that effect of glycopyrrolate on nausea and vomiting during cesarean section are comparable to ondansetron, but with an increased incidence of dry mouth. ${ }^{24}$

Ketamine is an intravenous dissociative anaesthetic agent related to phencyclidine group which works by antagonizing $\mathrm{N}$-methyl D-aspartate (NMDA) receptors. ${ }^{6}$ Because of its unique analgesic and dissociative criteria in addition to the distinct symatho-mimetic, vagolytic pharmacological properties, ketamine is used frequently in anaesthesia practice for purposes of analgesia, sedation and induction of anaesthesia many years ago. Ahmed hasnain and A M Shabana used low dose ketamine infusion in CS and found reduction in incidence of nausea. ${ }^{25,26}$ The APGAR score at $1 \mathrm{~min}$ and $5 \mathrm{~min}$ in all the neonates was more than 9. Ketamine use during CS has been found safe interms of both maternal and fetal safety, with neonatal 1 min and 5 min APGAR scores being more than 9 when used as IV inducing agent in $\mathrm{CS}^{27}$ Ketamine use intrathecally as adjuvant to bupivacaine in CS has also shown to stablise haemodynamics and decrease the incidence of nausea and vomiting. ${ }^{28}$ There was statistically significant decrease in incidence of IONV in ketamine and ondansetron group as compared to control group. The antiemetic effect of low dose ketamine and ondansetron was comparable.

The ketamine group showed statistically insignificant higher HR and MAP compared to ondansetron and control group. This can be explained to sympathomimetic and vagolytic propetrties of ketamine.

There were 11 patients in ketamine group with higher sedation levels (RSS $=3$ or more), although Ketamine use during spinal anaesthesia nor was it associated with increased incidence of either respiratory depression or hallucinations. The non-significant difference in the sedation level measured by RSS can be explained because of low dose of ketamine used in contrast to ketamine used for sedation in higher doses $(0.5 \mathrm{mg} / \mathrm{kg} / \mathrm{hr}$ or higher $)$ or in combination with midazolam. ${ }^{29}$

The incidence of shivering in ketamine group was lower as compared to control group and overall shivering incidence was lower than reported due to use of intrathecal fentayl. Ketamine is competitive receptor antagonist of Nmethyl-D-aspartic acid (NMDA) has a role in thermoregulation in various levels. Ketamine probably controls shivering by non- shivering thermo genesis either 
influencing the hypothalamus or by the beta-adrenergic effect of nor epinephrine. ${ }^{30}$

\section{Conclusion}

Low dose ketamine and ondansetron are both good agents for reduction of IONV during CS in pregnant patients under spinal anaesthesia without significant adverse effect.

\section{Source of Funding: Self-funded.}

\section{Conflict of Interest: None.}

\section{References}

1. Juhani TP, Hannele H. Complications during spinal anesthesia for cesarean delivery: a clinical report of one year's experience. Reg Anesth 2000;18:128-31.

2. Balki M, Carvalho JC. Intraoperative nausea and vomiting during cesarean section under regional anesthesia. Int J Obstet Anesth 2005;14(3):230-41.

3. Pan $\mathrm{PH}$, Moore $\mathrm{CH}$. Intraoperative antiemetic efficacy of prophylactic ondansetron versus droperidol for cesarean section patients under epidural anesthesia. Anesth Analg 1996;83:982-6.

4. Kestin IG. Spinal anesthesia in obstetrics. $\mathrm{Br} \mathrm{J}$ Anaesth 2004;66:596-607.

5. Szarvas S, Chellapuri RS, Harmon DC, Owens J, Murphy D, Shorten GD. A comparison of dexamethesone, ondansetron and dexamethasone plus ondansetron as prophylactic antiemetic and antipruritic therapy in patients receiving intrathecal morphine for major orthopedic surgery. Anesth Analg 2003;97:259-63.

6. Morgan EJ, Mikhail MS, Murray JM. Nonvolatile anesthetic agents, clinical anesthesiology, vol. 1. 4th ed. Lange Medical Books/McGraw-Hill;2006. p. 179-204.

7. Tyler, MW; Yourish, HB; Ionescu, DF; Haggarty, SJ. Classics in Chemical Neuroscience: Ketamine. ACS Chem Neurosci 2017;8(6):1122-34.

8. Watcha MF, White PF. Postoperative nausea and vomiting: its etiology, treatment, and prevention. Anesthesiol 1992;77:162.

9. Datta S, Alper MH, Ostheimer GW, Weiss JB. Method of ephedrine administration and nausea and hypotension during spinal anesthesia for cesarean section. Anesthesiol 1982;56:6870.

10. Rabey PO, Smith O. Anaesthetic factors contributing to postoperative nausea and vomiting. Br J Anaesth 1992;69:40S$5 \mathrm{~S}$.

11. Hesketh PJ. Comparative review of 5-HT3 receptor antagonists in the treatment of acute chemotherapy-induced nausea and vomiting. Cancer Investig 2000;18:163-73.

12. Pan $\mathrm{PH}$, Moore $\mathrm{CH}$. Intraoperative antiemetic efficacy of prophylactic ondansetron versus droperidol for cesarean section patients under epidural anesthesia. Anesth Analgesia 1996;83:982-6.

13. Leeser J, Lip H. Prevention of postoperative nausea and vomiting using ondansetron, a new, selective, 5-HT3 receptor antagonist. Anesth Analgesia 1991;72:751-5.

14. Scuderi P, Wetchler B, Sung YF, Mingus M, DuPen S, Claybon L, et al. Treatment of postoperative nausea and vomiting after outpatient surgery with the 5-HT3 antagonist ondansetron. Anesthesiol 1993;78:15-20.

15. Balki M, Carvalho JC. Intraoperative nausea and vomiting during cesarean section under regional anesthesia. Int J Obstet Anesth 2005;14:230-41.

16. Datta S, Alper MH, Ostheimer GW, Weiss JB. Method of ephedrine administration and nausea and hypotension during spinal anesthesia for cesarean section. Anesthesiol 1982;56:68 70.

17. Dershwitz M, Conant JA, Chang Y, Rosow CE, Connors PM. A randomized, double-blind, dose-response study of ondansetron in the prevention of postoperative nausea and vomiting. J Clin Anesth 1998;10:314-20.

18. Griffiths JD, Gyte GM, Paranjothy S, Brown HC, Broughton HK, Thomas J. Interventions for preventing nausea and vomiting in women undergoing regional anaesthesia for caesarean section. Cochrane Database Syst Rev 2012;12;9.

19. Santos A, Datta S. Prophylactic use of droperidol for control of nausea and vomiting during spinal anaesthesia for caesarean delivery. Anesth Analg 1984;63:85-7.

20. Mandell GL, Dewan DM, Howard G, Floyd HM. The effectiveness of low dose droperidol in controlling nausea and vomiting during epidural anesthesia for cesarean section. Int $J$ Obstet Anesth 1992;1:65-8.

21. De Oliveira GS Jr, Castro-Alves LJ, Ahmad S, Kendall MC, McCarthy RJ. Dexamethasone to prevent postoperative nausea and vomiting: an updated meta-analysis of randomized controlled trials. Anesth Analgesia 2013;116:58.

22. Fujii Y, Tanaka H, Toyooka H. Prevention of nausea and vomiting with granisetron, droperidol and metoclopramide during and after spinal anaesthesia for caesarean section: a randomized, double-blind, placebo-controlled trial. Acta Anaesthesiol Scand 1998;42:921-5.

23. Wu JI, Lo Y, Chia YY, Liu K, Fong WP, Yang LC, Tan PH. Prevention of postoperative nausea and vomiting after intrathecal morphine for Cesarean section: a randomized comparison of dexamethasone, droperidol, and a combination. Int J Obstet Anesth 2007;16:122-7.

24. Ragi Jain, Rashmi Sharma. A comparative study of effects of glycopyrrolate and ondansetron on nausea and vomiting in cesarean section under spinal anesthesia. Anaesth Essays Res 2015;9(3):348-52.

25. Ahmed Hassnaen, Eissa Mahmoud. Effect of low dose ketamine versus dexamethasone on intraoperative nausea and vomiting during cesarean section under spinal anesthesia. Egypt J Anaesth 2015;31(1):59-63.

26. A.M. Shabana, E.S. Nasr, H.E. Moawad. Effect of ketamine on intraoperative nausea and vomiting during elective caesarean section under spinal anaesthesia: A placebo-controlled prospective randomized double blinded study. Egypt J Anaesth 2012;28 (2):169-74.

27. $19 \mathrm{~m}$. Nielsen JD, Holasek J. Ketamine as induction agent for caesarean section. Acta Anaesthesiol Scand 1982;26:139-42.

28. Ahmed Sobhy Basuni. Addition of low-dose ketamine to midazolam and low-dose bupivacaine improves hemodynamics and postoperative analgesia during spinal anesthesia for cesarean section. J Anaesthesiol Clin Pharmacol 2016;32(1):44-8.

29. Saricaoglu F, Dal D, Akgun ES, Doral MN, Kılınc K, Aypar U. Ketamine sedation during spinal anesthesia for arthroscopic knee surgery reduced the ischemia-reperfusion injury markers. Anesth Analg 2005;101:904.

30. Sagir O, Gulhas N, Toprak H, Yucel A, Begec Z, Ersoy O. Control of shivering during regional anaesthesia: prophylactic ketamine and granisetron. Acta Anaesthesiol Scand 2007;51:44-9.

How to cite this article: Nazir $\mathrm{O}$, Bhat $\mathrm{AH}$, Yatoo $\mathrm{H}$, Khatuja A, Misra R. Comparison of ondansetron and low dose Ketamine as agents for prevention of intraoperative nausea and vomiting during caesarean section under spinal anaesthesia. Indian J Clin Anaesth 2019;6(2):25862. 